International Journal of Economics, Business and Accounting Research (IJEBAR)

Peer Reviewed - International Journal

Vol-4, Issue-3, 2020 (IJEBAR)

E-ISN: 2614-1280 P-ISSN 2622-4771

http://jurnal.stie-aas.ac.id/index.php/IJEBAR

\title{
WORKING CAPITAL RELATIONSHIP WITH FIRM PROFITABILITY AND SIZE
}

\author{
Muhammad Ahsan Kabir ${ }^{1}$, Azeddine Elalami Lahlimi ${ }^{2}$, Abdulmalik Muhammad Junaidu', \\ Issah Sham-Una ${ }^{4}$, Muneeb Ahmad ${ }^{5}$ \\ 1Zhejiang Gongshang University, Hangzhou, China, 2,3,4,5 Jiangxi University of Finance and Economics \\ Email: muneeb112@gmail.com
}

\begin{abstract}
Working Capital (WC) turnover as far as days has been viewed as a valuable proportion of company's powerful liquidity and money the board. This investigation was directed through the plan to inspect the connection of the WC through the size as well as advantage of the businesses in the four explicit accumulated areas evidenced on Karachi Stock Exchange to be specific Petroleum Limited, Engineering Works, Textile Mills, and Garments manufacturers. The knowledge was collected recognizing with the 40 tested organizations out of the aggregate in the related parts for example 185 covering the time of 2016-2019 by using ANOVA analysis and Pearson's correlation test. This examination in attendance informs documentation of the assessment about the issue of money the board a zone that isn't especially explored ahead in the generated nations similar to Pakistan. The current examination includes different supportive consequences that ought to be practiced for the account directors, manufacturing organizations, educationists and specialists.
\end{abstract}

Keywords: Working Capital Management, Liquidity, Pearson's Correlation, Profitability, ANOVA Analysis

\section{Introduction}

Documentation is seen as the spirit of industry; fruitful financial organization is basic for the business continuance and extraordinary turn of events. Essentially every assessment concerning the currency the board are seen a lot critical as they communicate to a much inadequate as well as the nearly all significant reserve of the companies worldwide. Essentially all the conclusions concerning the record administrators identifying with this huge resource have a great deal of bearing upon the presentation, peril and the market estimation of the associations.

There exists a critical and depressing relationship between profit and liquidity estimates, such as, present amount with cash opening. The examination found that CR is the most significant liquidity measure that influences gainfulness (Eljelly, 2004). The positive and critical relationship between's the venture and financing approaches for businesses demonstrate that enterprises which seek after forceful speculation working capital strategies will in general follow traditionalist working capital financing arrangements (Shah, 2011). Jahan, 2011 determined critical negative straight connections among the Working capital management (WCM) and the firm size presents, particularly as far as net deals. Along these lines, little scope producing firms have longer Working capital management (WCM) and the other way around. 
International Journal of Economics, Business and Accounting Research (IJEBAR)

Peer Reviewed - International Journal

Vol-4, Issue-3, 2020 (IJEBAR)

E-ISN: 2614-1280 P-ISSN 2622-4771

http://jurnal.stie-aas.ac.id/index.php/IJEBAR

According to Elham, 2012, an expansion in net working capital will prompt increment in organization's benefit and the relationship coefficients for all proportions of working capital administration are noteworthy aside from Working capital management (WCM). Working capital management reverse influences profit of capital and income for significance; therefore currency change pattern of accumulating industries is defiantly recognized through the productivity of the associations (Raheem Anser, 2013). Money Change Cycle is having without a doubt positive relationship with both advantage for resources and worth Strikingly, there is short investment are accepted in current resources with as time goes and constantly assets conjecture powerful just before a higher productivity of industries (Panigrahi, 2013).

Safiah, 2015, described the impact of working capital management on profitability in the organizations enrolled in Kuala Lumpur Stock Exchange isn't significant and the impact of working capital on to estate and oil is unimportant. The working liquidity and budgetary influence of the firm; both influence and liquidity are critical in deciding the presentation of the firm. The low degree of obligation and high liquidity are instrumental in improving the exhibition of capital serious apparatus firms (Utkarsh Goel, 2015). The two impacts and sets up a curved connection among WCM and firm benefit. The presence of working capital level which expands firm productivity, deviations from the ideal level decrease firm gainfulness; consequently, WCM is a significant component for firms (Afrifa, 2016).

This examination anyway anticipated optimistic link among Working capital management (WCM) and gainfulness (Murtala Zakari, 2016). The relationship between the WCM and advantage isn't seen as fundamental by uprightness of making and made economies. In any case, by ethicalness of enormous firms and SMEs, the affiliation is seen as basic, which induces that the firm size fills in as an organizing variable in this association (Satish, 2017). Dina Korent, 2018 examined the budgetary administration about the distribution of assets fundamentally needs to manage the choices with respect to the monetary structure, money related evaluation, and the working capital administration (WCM). This affiliation isn't widespread to all ventures, or to every single firm size. In particular, the pessimistic connection among cash to cash length and future profit is just seen in the assembling business (Binod Guragai, 2019).

According to numerous analysis's, the working capital management (WCM) is a fragment of money the executives and is viewed as a significant factor in improving organizations (Ilhan Dalci, 2019). Liquidity is a marker with beneficial outcome in both ROA and ROE however a negative impact on the other productivity proportion examined by (Thi Ngoc, 2020). Its liquidity and suitability and in contrast with the market's chief and to a comparative customary firm, the overwhelming financial emergency, new organizations can endure and develop and this is an idealistic message towards experts and strategy creators the same (Sophia Nema, 2020).

There are different explores concerning WCM and its effect on the association's bit of leeway yet just a few examines have been guided in Pakistan as for the WCM relationship with the affiliation's profitability and size. So the fundamental inspiration of the current appraisal is to look at and comprehend the chance of the relationship of WCM with the size and benefit of the relationship from four present day parts of Pakistan. The WCM turnover days and the association's size, the WCM turnover days and the association's advantage the portrayed explanation of the issue to be examined, One Are the firm size and effectiveness are associated with the WCM time run? The particular examination goals are to outline the suffering synthesis on WCM and WCM to follow the models in the light of clear confirmation appreciate the significance WCM as a proportion of beneficial cash the board, appreciate the relationship of WCM with the association productivity and size. Services industry is measured ahead of this research focus as, is not tested. Through the total assets and sales returns the size of firm is calculated and the profitability ratios have been calculated by values of total assets and values of profits.

The remainder of this paper is organized as follows: Segment two includes an audit of surviving writing on the WCM; depicts the inspection viewpoint and examination pattern; segment three talks about 
International Journal of Economics, Business and Accounting Research (IJEBAR)

Peer Reviewed - International Journal

Vol-4, Issue-3, 2020 (IJEBAR)

E-ISN: 2614-1280 P-ISSN 2622-4771

http://jurnal.stie-aas.ac.id/index.php/IJEBAR

the findings and their analysis; the forth segment finishes up the investigation gives proposal to the future examination in the subject.

\section{Methodology}

\subsection{Single direction ANOVA}

The current assessment was basically leaded to investigate the speculated associations through affiliation examination and single bearing ANOVA analysis. The correlation measurement is utilized for searching for the particular associations with the WCM span and size of firm. For the WCM turnover days for the separation over the endeavors the single direction ANOVA analysis is utilized. Since the rule focus of the energy research was to evaluate the correlation of WCM turnover days with the size and profitability of firms.

Organization firms are considered past the inspiration driving the assessment and henceforth not tried. The firm size was spoken to by the estimations of both the full scale assets and arrangements pay, and the advantage extents were spoken to by the estimations of advantages on esteem similarly as on the hard and fast assets. The WCM length is assessed by processing records of deals, stock and records payable. The firm size was spoken to by the estimations of both the total assets and arrangements pay. Productivity extents were spoken to by the \% benefits on esteem and on the total assets.

\section{Results and Conclusions}

\subsection{Data Collection Techniques}

One-Way ANOVA analysis is to be accomplished to examine the relevant divergence of the WCM turnover days among the industries involved in the study. Secondly, to show the correlation of WCM with profitability and firm size we applied Pearson's correlation analysis

Table 1 Representing selected firms Mean values in percentage

\begin{tabular}{|c|c|c|c|c|c|c|}
\hline Name of Industry & & WCM days & $\begin{array}{r}\text { Return on } \\
\text { Equity } \\
\text { Share\% } \\
\end{array}$ & $\begin{array}{r}\text { Total Assets } \\
\text { return \% }\end{array}$ & Total Assets & Total sales \\
\hline Petroleum Limited & $\begin{array}{c}\text { Mean } \\
\mathrm{N}\end{array}$ & $\begin{array}{c}22.04 \\
60\end{array}$ & $\begin{array}{c}0.223465 \\
60\end{array}$ & $\begin{array}{c}0.07879343 \\
60\end{array}$ & $\begin{array}{c}4551368717.42 \\
60\end{array}$ & $\begin{array}{c}70345678617.22 \\
60\end{array}$ \\
\hline \multirow{3}{*}{$\begin{array}{l}\text { Engineering } \\
\text { Works }\end{array}$} & $\begin{array}{c}\text { Std. } \\
\text { Deviation }\end{array}$ & 70.224 & 0.4245656 & 0.2100390 & 4554123456.332 & 9878766656.677 \\
\hline & Mean & -62.41 & 0.0407872 & 0.0297287 & 30876765654.34 & 9397865653.862 \\
\hline & $\mathrm{N}$ & 35 & 35 & 35 & 35 & 35 \\
\hline \multirow{3}{*}{ Textile Mills } & $\begin{array}{c}\text { Std. } \\
\text { Deviation }\end{array}$ & 43.522 & 0.3445162 & 0.091347 & $\begin{array}{c}34251324456.12 \\
3\end{array}$ & 7826753267.245 \\
\hline & Mean & 41.46 & 0.3464521 & 0.255234 & $\begin{array}{c}27813452972.34 \\
2\end{array}$ & 23454517850.91 \\
\hline & $\mathrm{N}$ & 60 & 60 & 60 & 60 & 60 \\
\hline Garments & $\begin{array}{l}\text { Std. } \\
\text { Deviation } \\
\text { Mean } \\
\text { N }\end{array}$ & $\begin{array}{c}45.561 \\
72.81 \\
30\end{array}$ & $\begin{array}{c}0.1945179 \\
0.3087673 \\
30\end{array}$ & $\begin{array}{c}0.45352334 \\
0.09664512 \\
30\end{array}$ & $\begin{array}{c}23411883422.45 \\
1 \\
8717652345.231 \\
30\end{array}$ & $\begin{array}{c}18725423217.09 \\
3 \\
16924572386.34 \\
30\end{array}$ \\
\hline
\end{tabular}


International Journal of Economics, Business and Accounting Research (IJEBAR)

Peer Reviewed - International Journal

Vol-4, Issue-3, 2020 (IJEBAR)

E-ISN: 2614-1280 P-ISSN 2622-4771

http://jurnal.stie-aas.ac.id/index.php/IJEBAR

\begin{tabular}{cc|c|c|c|c|c|} 
& Std. & 30.041 & 0.2345567 & 0.0688421 & 8903456453.456 & 21366893234.56 \\
1 & \\
Total & $\begin{array}{c}\text { Deviation } \\
\text { Mean }\end{array}$ & 20.71 & 0.2453341 & 0.0793672 & 21454577523.56 & 21342345345.35 \\
& $\mathrm{~N}$ & 185 & 185 & 185 & 185 & 185 \\
& Std. & 60.245 & 0.307845 & 0.172889 & 16788347868.23 & $\begin{array}{c}21613234999.65 \\
4\end{array}$ \\
\hline
\end{tabular}

The Concrete solid business has shown the most capable WCM turnover to the extent days averaging about (- 62.41), and the Pieces of clothing firms region have the best pace of WCM turnover days averaging 72.81 generally. The single bearing ANOVA examinations were performed close by the Duncan test and the Post-Hoc tests (Table 2 and 3). An extraordinarily basic F-estimation of 56.23 with respect to the WCM length over the organizations was viewed. Along these lines we excuse the invalid theory that the techniques are not identical over the endeavors pondered and can surmise that there appear to be basic complexities among the ventures similar to the WCM length. Furthermore by Post-Hoc assessment we can also assume that among all organizations average of Solid business WCM is inside and out extraordinary corresponding to foodstuff and compound endeavors.

Table 2 WCM days and One-way ANOVA Analysis

\begin{tabular}{|r|r|r|r|r|r|}
\hline & $\begin{array}{c}\text { Summation of } \\
\text { Squares }\end{array}$ & Df & $\begin{array}{c}\text { Mean } \\
\text { Square }\end{array}$ & F & Significance \\
\hline Among Groups & 345867.345 & 5 & 89856.352 & 56.234 & 0.000 \\
Between Groups & 321234.234 & 165 & 2465.234 & & \\
Total & 632267.342 & 149 & & & \\
\hline
\end{tabular}

Industry $\mathrm{N}$ separation for alpha $=0.05$

Table 3 WCM days Duncan a, b test Means for groups

\begin{tabular}{|r|r|r|r|r|}
\hline Firm Names & N & \multicolumn{3}{|c|}{ Separation used for alpha $=\mathbf{0 . 0 6}$} \\
\hline Cement & 35 & -64.29 & 2 & 3 \\
Sugar & 60 & & 34.23 & \\
Chemical & 60 & & 45.27 & \\
Auto Mobiles and Parts & 30 & & & 67.89 \\
Sig. & & 1.000 & 0.345 & 1.000 \\
\hline
\end{tabular}

a, used Harmonic Mean section $=35.345 . \mathrm{b}$, the assembly sizes are asymmetrical. The Type I inaccuracy elevation are not certain.

\subsection{Firm Size and WCM Correlation}

The Concrete solid business has exhibited the most capable WCM turnover to the extent days averaging about (- 62.41), and the Articles of clothing firms zone have the best pace of WCM turnover days averaging 72.81 generally. The single heading ANOVA examinations were performed nearby the Duncan test and the Post-Hoc tests (Table 2 and 3). A particularly basic F-estimation of 56.23 with respect to the WCM length over the organizations was viewed. Along these lines we excuse the invalid theory that the techniques are not equal over the endeavors examined and can derive that there appear to 
International Journal of Economics, Business and Accounting Research (IJEBAR)

Peer Reviewed - International Journal

Vol-4, Issue-3, 2020 (IJEBAR)

E-ISN: 2614-1280 P-ISSN 2622-4771

http://jurnal.stie-aas.ac.id/index.php/IJEBAR

be basic complexities among the undertakings to the extent the WCM length. Furthermore by Post-Hoc assessment we can also assume that amongst all organizations average of Solid business WCM is through and through interesting comparable to those of the Food and Compound endeavors.

Table 4 Representation of Correlation Analysis Matrix

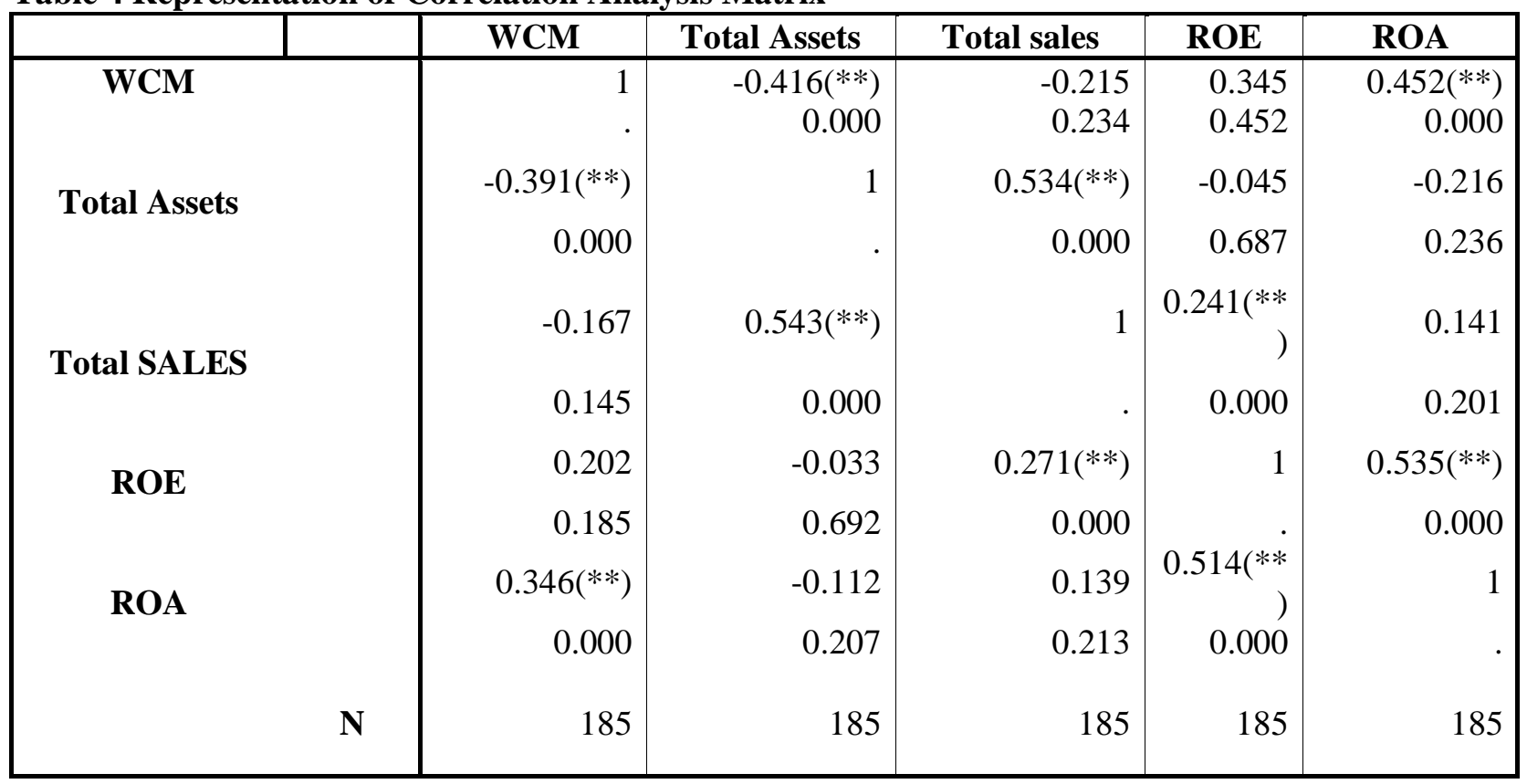

Notes: $*$ (2-tailed) Correlation Significant at 0.05 levels. $* *$ (2-tailed) Correlation significant at 0.01 levels

\subsection{Correlation of WCM and Profitability}

Strikingly, now emerges to be an enormous positive association between's WCM turnover in days and the benefit the extent that benefit for full scale assets offering a strong hint to industries owners which is progressively expanded the WCM proceeds in days, smaller capital can be used in progressive assets with progressively fixed capital endeavor driving a high efficiency. This technique for thinking is moreover supported by the possibility of perfect liquidity arrangement by Schilling (1996). The WCM time span and benefit for esteem emit an impression of being unfavorably associated with the organization's profit (- 0.167) revealing the evidence, behind the past assessment to the associations with shorter WCM proceeds. This might be a direct result of the way to the associations including further prominent theory, yet pretty expensive outside wellsprings of money to back their working capital similarly as their fixed assets. Due to which their advantage is reduced as affirm by the negative relationship of the outright assets with the profitability both in regards to the appearance on esteem similarly as the appearance on assets.

\section{Conclusion}

The examination of the mean estimations of WCM time frame for different businesses shows that the larger industries become visible to contract by their WCM returns days productively while associates occurring by their money cycle the executives. In addition, the WCM time frame and the firm size, as far 
International Journal of Economics, Business and Accounting Research (IJEBAR)

Peer Reviewed - International Journal

Vol-4, Issue-3, 2020 (IJEBAR)

E-ISN: 2614-1280 P-ISSN 2622-4771

http://jurnal.stie-aas.ac.id/index.php/IJEBAR

as absolute resources just as the all out deals, have a solid negative relationship. Unusually, a critical positive relationship of the WCM time frame and the gainfulness regarding return on all out resources gives a firm sign to the industry administrators drawn to WCM proceeds days, smaller capital will be suggested in existing resources. The WCM time frame as well as proceeds cost give off sense of being perversely related among the relations productivity (-0.131) recognition with behind the precedent examination discovery which the businesses through smaller WCM earnings days are more beneficial than the organizations with longer WCM. The investigation is the focus directed in Pakistan moreover presents some helpful benchmarks regarding WCM turnover days to the organizations in the related business to re-examine.

Further analysts could conveniently test and check the focuses expanded in this examination over a more noteworthy arrangement of businesses. Specifically, so as to distinguish the different conditions wherein the organizations could change their mentalities towards specific wellsprings of working capital, and that in the various periods of development cycle, the longitudinal examinations using ideally the board or pooled information may demonstrate increasingly supportive. A decent measure of exploration work may likewise be attempted with the target of proposing a perfect blend of WCM systems and the money related approaches which could be exceptionally helpful for the development of the organizations.

\section{Acknowledgments}

The authors would like to thank the supervisor for support of this research.

\section{References}

Afrifa, G. A. (2016). Working capital level influence on SME profitability. Journal of Small Business and Enterprise Development , 44-63.

AlHajjar, H. N. (2011). Cash conversion cycle and firm's performance. Asian Review of Accounting , 147-156.

Binod Guragai, P. D. (2019). Cash to Cash length: Insights on Present and Future profitability and liquidity . Advances in Management Accounting Copyright (C) 2019 by Emerald Publishing Limited , 133-151.

Dina Korent, S. O. (2018). The Impact of Working Capital Management on Profitability of Croatian Software Companies. Zagreb International Review of Economics \& Business, Vol. 21, No. 1 , 47 65.

Elham, T. K. (2012). Working capital management and corporate performance: evidence from Iranian companies. Procedia - Social and Behavioral Sciences , 1313 - 1318.

Eljelly, A. M. (2004). Liquidity - profitability tradeoff: An empirical investigation in an emerging market. International Journal of Commerce and Management , 48-61.

Fahmida Laghari, Y. C. (2019). Investment in working capital and financial constraints: Empirical evidence on corporate performance. International Journal of Managerial Finance , 1-28.

Ilhan Dalci, C. T. (2019). The Moderating Impact of Firm Size on the Relationship between Working Capital Management and Profitability. Prague Economic Papers, 1-18.

Jahan, N. (2011 ). An Empirical Investigation of Cash Conversion Cycle of Manufacturing Firms and its Association with Firm Size and Profitability. Bank Parikrama, 18-32.

Murtala Zakari, S. S. (2016). The Impact of Cash Conversion Cycle on Firm Profitability: Evidence from Nigerian Listed Telecommunication Companies . Journal of Finance and Accounting http://www.sciencepublishinggroup.com/j/jfa , 342-350 .

Panigrahi, D. A. (2013). Cash Conversion Cycle and firms' profitability- A study of cement manufacturing companies of India. International Journal of Current Research , 1484-1488. 
International Journal of Economics, Business and Accounting Research (IJEBAR)

Peer Reviewed - International Journal

Vol-4, Issue-3, 2020 (IJEBAR)

E-ISN: 2614-1280 P-ISSN 2622-4771

http://jurnal.stie-aas.ac.id/index.php/IJEBAR

Raheem Anser, Q. A. (2013). Cash Conversion Cycle and Firms' Profitability - A Study of Listed Manufacturing Companies of Pakistan . IOSR Journal of Business and Management Volume 8, Issue 2, 83-87.

Schilling, G., (1996). "Working capital's role in maintaining corporate liquidity", TMA Journal, Vol. 16 No. 5, pp. 4-7.

Safiah, F. (2015). The effects of Working Capital Management on the profitability of plantation and pertroleum sector in Malaysia. International Journal of Accounting \& Business Management , 87108.

Satish, H. P. (2017). Working Capital Management and Firm Profitability: A Meta-Analysis . Qualitative Research in Financial Markets , 1-21.

Shah, N. A. (2011). Relationship of Cash Conversion Cycle with Firm Size, Working Capital Approaches and Firm's Profitability: A Case of Pakistani Industries. Pakistan Journal of engineering and technical sciences , 45-64.

Shamsaldin Jamalinesari, H. S. (2015). The Relationship between the E fficiency of Working Capital Management Companies and Corporate Rule in Tehran Stock Exchange. Procedia - Social and Behavioral Sciences , 499-504.

Sophia Nema, K. L. (2020). The Effect of the Cash Conversion Cycle on the Z-scores of Fresh Milk Companies in Greece. Economic Alternatives , 105-137.

Thi Ngoc Lan NGUYEN, V. C. (47-58 ). The Determinants of Profitability in Listed Enterprises: A Study from Vietnamese Stock Exchange. Journal of Asian Finance, Economics and Business Vol 7 No 1 , 2020.

Utkarsh Goel, S. C. (2015). Operating liquidity and financial leverage: E vidences from Indian machinery industry . Procedia - Social and Behavioral Sciences , $344-350$. 